\title{
Assessment of Frequency of Cigarette Smoking Behavior Among High School Students and Their Knowledge, Attitude and Behaviors About Cigarette Smoking
}

\section{Lise Öğrencilerinde Sigara İçme Sıklığı, Bunu Etkileyen Faktörler Ve Öğrencilerin Sigara İle illgili Bilgi, Tutum, Davranışlarının Değerlendirilmesi}

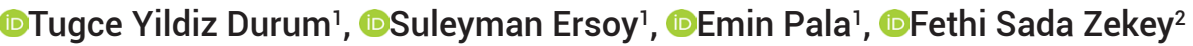 \\ 'University of Health Sciences Umraniye Training and Research Hospital, Department of Family Medicine, Istanbul, Turkey
}

${ }^{2}$ Yozgat Bozok University, Faculty of Medicine, Department of Family Medicine, Yozgat, Turkey

Copyright@Author(s) - Available online at www.dergipark.org.tr/tr/pub/medr

Content of this journal is licensed under a Creative Commons Attribution-NonCommercial 4.0 International License.

\begin{abstract}
Aim: In our study, we wanted to evaluate the frequency of smoking in high school students, the related factors and the knowledge, attitude and behaviors of students about smoking.

Material and Methods: High school students between the ages of 14-18 were included in the study. The data were gathered using the questionnaire method. The questions were about the sociodemographic characteristics of the students, their smoking status, whether there are individuals who smoke in the family, the knowledge level of the students about the harms of smoking, and their attitudes towards smoking.

Results: The study was conducted with a total of 406 students, 187 (46.1\%) girls and 219 (53.9\%) boys. 16.3\% of the student's smoke, $83.7 \%$ do not smoke, and $3 \%$ quitted smoking. As a result of paired comparisons; the smoking rate of students of the 9 th grade was found to be significantly lower than the 10th, 11 th and 12th grade $(p=0.039 ; p=0.001 ; p<0.001)$. The smoking rate of 12 th grade students was found to be statistically significantly higher than the 10 th and 11 th grades $(p=0.001 ; p=0.024)$. 39.4\% of the students started smoking due to social factors and $34.8 \%$ because of pleasure. The relationship between smoking status of the students and male gender, father's education status, smoking status of siblings and smoking status of close friends were found to be statistically significant $(p<0.001, p=0.017, p<0.001$ and $p<0.001$ respectively).

Conclusion: It was found in our study that a certain percentage of high school students smoke and these rates increase from the $1 \mathrm{st}$ to the 4 th grade.
\end{abstract}

Keywords: Smoking; high school students; behavior

Öz

Amaç: Çalışmamızda lise öğrencilerinde sigara içme sıklığını, bunun hangi faktörlerle ilişkili olduğunu ve öğrencilerin sigarayla ilgili bilgi, tutum, davranışlarını değerlendirmek hedeflenmiştir.

Materyal ve Methot : Çalışmaya Ümraniye ilçesindeki 2019-2020 öğretim yılının ikinci yarısında öğrenim gören, 14-18 yaş arasındaki lise öğrencileri dahil edilmiştir. Veriler anket yöntemi kullanılarak toplanmıştır. Anket formu öğrencilerin sosyodemografık özellikleri, sigara içme durumları, ailede sigara içen bireylerin olup olmadığı, öğrencilerin sigaranın zararlarıyla ilgili bilgi düzeyleri ve sigara kullanımına yönelik tutumlarını öğrenmeye yönelik sorulardan oluşmuştur.

Bulgular. Çalışma 187'si (\%46.1) kadın ve 219'u (\%53.9) erkek olmak üzere toplam 406 öğrenci ile yapılmıştır. Çalışmamıza katılan öğrencilerin \%16.3'ü sigara kullanmakta, \%83.7'si kullanmamaktadır, \%3'ü sigarayı bırakmıştır. 9.sınıftakilerin sigara kullanma oranı 10,11 ve 12. sınıflardan anlamlı düzeyde düşük bulunmuştur ( sırasıyla $p=0.039 ; p=0.001 ; p<0.001$ ). 12. sınıftakilerin sigara kullanma oranı 10.sınıf ve 11.sınıftakilerden anlamlı düzeyde yüksek bulunmuştur (sırasıyla $p=0.001 ; p=0.024$ ). Öğrencilerin \%39.4'ü sosyal faktörler, \%34.8'i keyif alma nedeniyle sigaraya başlamıştır. Öğrencilerin sigara içme durumunun; erkek cinsiyet, baba öğrenim durumu, kardeşlerin sigara içme durumu ve yakın arkadaşın sigara içme durumu ile ilişkisi anlamlı bulunmuştur (sırasıyla p<0.001, $p=0.017, p<0.001$ ve $p<0.001)$.

Sonuç: Çalışmamızda lise öğrencilerinin önemli bir oranda sigara kullandığı ve bu oranların 1.sınıftan 4.sınıfa doğru arttığı görülmüştür.

Anahtar Kelimeler. Sigara içme; lise öğrencileri; tutum ve davranış 


\section{INTRODUCTION}

Cigarette smoking is $1 \mathrm{st}$ in ranking among preventable diseases and causes of mortality globally. According to WHO data out of 56,9 million deaths annually worldwide 8 million are due to tobacco consumption and one million are due to passive exposure to tobacco smoke (1). Cigarette smoking is also a significant risk factor for diseases with high mortality (2). Moreover, a great many types of cancer and diseases such as oral and oropharyngeal cancers, esophagus-stomach cancers, hepatic cancer, bladder cancer, colorectal cancer, pancreas cancer, cervix cancer, congenital defects, impairment of immunologic functions, macular degeneration, psoriasis, crohn disease are associated with smoking (3). The first pandemic of the 21 st century is COViD- 19 pandemic which was declared by Chinese government on 31st December 2019 as originated from Wuhan city of Hubei province that is usually complicated by pneumonia during the course of the illness and which may pose a threat in global scale and which was declared as spread to 113 countries by 11 th March 2020. It's observed that addiction to cigarette smoking increases severity and mortality of the disease (4).

Although it's a widespread and mortal bad habit, the long time span between starting smoking and observing its negative outcomes lead to negligence of the harmful effects of addiction to cigarette smoking (5).

First encounter with addictive substances such as cigarette, alcohol and illicit drugs usually occurs in adolescence (6). Those who start smoking at adolescence become more addicted to smoking and also, it's more difficult to quit smoking for them. Probability of becoming addicted to smoking is higher among people who start smoking before 21 years of age (7). In adolescence whim, family problems, misbehaviors of parents, effects of peer pressure, prove himself/herself as to become an adult, environmental factors, presence of smokers within the family circle, absence of a proper role model, promotion of smoking by mass-media and inability to say no are seems to be the various factors for tendency to smoke cigarette.

The World Tobacco-free Day campaign that was held on 31 st May 2020 by the World Health Organization (WHO) aims to protect children and people from the tobacco industry and being abused by related industries. WHO states that 9 smokers out of 10 start smoking cigarettes before 18 years old and this year WHO prepared an education set for high school students in order to warn them against tactics of the tobacco industry to make youngsters addicted to smoking cigarettes (8).

Twenty three percent of the deaths in our country result from diseases related with cigarette smoking. Every year 110000 individuals die due to cigarette smoking (9). In our country, in 2017, Global Youth Tobacco Survey (GYTS) was performed in students between 13-15 years old; accordingly, $17.9 \%$ of the students $(23.2 \%$ of males and $12.1 \%$ of females are current smokers of some kind of a tobacco product. $40.2 \%$ of the students have tried tobacco products at least once (10).

In our study carried out in students between 14-18 years old who are attending high schools in Ümraniye county were assessed whether there is a significant difference in smoking frequency of the students based on their sociodemographic and socioeconomic characteristics. We aimed to answer the questions such as, "how much knowledge do they have about smoking and how are their attitudes and behaviors about smoking? What's the frequency of smoking?" and to assess that knowledge, attitudes and behaviors and to determine necessary measures to prevent smoking. We think that our study may increase awareness of the students, parents and teachers about the subject and may give some ideas about designing the curriculum and arranging in-service training.

\section{MATERIAL AND METHODS}

\section{Selection of the students}

This was a cross-sectional descriptive study. It was carried out in various high schools of Ümraniye county in the second period of the 2019-2020 teaching year. After required permissions were obtained from Ümraniye County National Education Administration, data were acquired from the students during the guidance-consultancy lessons by directing the questions of the questionnaire prepared along with the Marmara Public Health team. For the study, students and their parents were informed about the survey and questionnaire form and primarily consent forms were given to parents. If the parents gave consent and signed the consent form, then written consent was also obtained from the students for participation into the study. The students were included into the study by considering below criteria.

Inclusion criteria for the students to participate into the study: 14-18 years old high school students.

Exclusion criteria for the students: Students younger than 14 years and older than 18; students who/whose parents didn't give consent for participating into the study.

\section{Sampling}

Umraniye county which was selected for the land of the study is the most crowded county in the Asian side of Istanbul and one of the most populous and multicultural district of the city. Other than conducting the study in Umraniye, in order to enable the generalization of the study, also the sampling of the students included into the study was done extensively as such: 23 state high schools and 20 private high schools are run under the status of Anatolian High School and Occupational Training Technical Anatolian high school within the city limits of Ümraniye county. A total of 32,975 students are attending these schools. In order to represent every type of school within the sample we planned to include students from 9th, 10th, 11th and 12th grades of Anatolian High Schools, Private Anatolian High Schools, Occupational and Technical 
Anatolian High Schools and Private Occupational and Technical Anatolian High Schools. After the students were stratified according to their school types, 4 schools were selected, by simple random sampling method, one from each stratum. Within each school, one class from each of the 9 th, 10th, 11th, 12th grades was randomly selected and questionnaires were applied to students in these classes. Moreover, student ts of the selected schools were the children of the families from various economical levels. When Power analysis effect size is 0.335 calculated by Gpower 3.1.0 program, at \%5 significance level and with $95 \%$ power, the sample size is found as 300 assuming smoking frequency is $20 \%$ based on prior studies.

\section{Statistical methods}

For assessment of the obtained results IBM SPSS Statistics 22 (IBM SPSS, Turkey) program was used for statistical analysis. For assessment of the obtained data descriptive statistical methods (mean, standard deviation, frequency) is used and moreover, for the comparison of qualitative data Chi-square test, Fisher's exact test, Fisher Freeman Halton test and Continuity (Yates) are used. Logistic regression was used for multivariate analysis. $\mathrm{P}<0.05$ was considered statistically significant.

\section{RESULTS}

The study was conducted with a total of 406 students, $187(46.1 \%)$ females and 219 (53.9\%) males. The ages of the students vary between 14-19 years and mean age was $16.08 \pm 1.21$ years. $42.6 \%$ of the students are living in non-smoking dwellings, $45.8 \%$ live in dwellings where smoking is possible in certain places and $11.6 \%$ live in dwellings where smoking is permitted. Mothers of $24.1 \%$ of the students smoke cigarettes and $75.9 \%$ don't smoke. Fathers of the $49 \%$ of the students smoke cigarettes and $51 \%$ don't smoke. Siblings of the $23.4 \%$ of the students smoke cigarettes, $76.6 \%$ don't smoke. Smoking close friends are the majority in $28.6 \%$ of the students and not in majority in \%71.4 of the students. Socio-demographic distribution of the students is shown in Table 1.

Distribution of the information about knowledge level and attitudes of the students regarding cigarette smoking is shown in table $2.16 .3 \%$ of the students participated in our study smoke, $83.7 \%$ do not smoke. $60.3 \%$ of the students have never tried smoking, $20.4 \%$ tried but didn't smoke and $3 \%$ quitted smoking. $30 \%$ of the students have knowledge about the functioning of smoking cessation outpatient units within the health institutions, but $70 \%$ don't have any knowledge about it. $96.8 \%$ of the students think smoking cigarettes is harmful for health and $3.2 \%$ think it's not harmful. $77.1 \%$ of the students think passive exposure to cigarette smoke is harmful for health but $22.9 \%$ don't think it's harmful for health. $31.8 \%$ of the students are exposed to cigarette smoke in their dwellings and $68.2 \%$ aren't exposed to (Table 2).
When we assess the distribution of information about smoking students, we observed that $24.2 \%$ have started smoking between $11-15$ years of age. $75.8 \%$ have started smoking after 16 years of age. $39.4 \%$ of the students have started smoking because of social factors, $34.8 \%$ because they get pleasure from it, $21.2 \%$ as a whim and $4.5 \%$ due to stress/stress. $77.3 \%$ of the students tried to quit smoking but $22.7 \%$ didn't try quit smoking. $15.2 \%$ of the students demand support to quit smoking, $66.7 \%$ don't demand any support and $18.2 \%$ are indecisive about it (Table 3).

Assessment of smoking status according to the type of the school or attended grade is shown in Table 4. There is a statistically significant difference between school types regarding smoking rate of the students $(p=0.013)$. When dual comparison between schools is done in order to detect the difference; it's found that smoking rate is lower in Anatolian high school students (10.4\%) relative to Occupational Training High Schools $(23.3 \%)(p=0.004)$. There is no difference regarding smoking rate of students in other types of schools $(p>0.05)$.

There is a significant difference regarding the rate of smoking students according to the attended grade $(p<0.001)$. Dual comparisons carried out to detect the differences has revealed that smoking rates of 9th grade students are statistically significantly lower than 10th, 11 th, 12th grade students (respectively, $\mathrm{p} 1=0.039$; $p 2=0.001 ; p 3<0.001)$. Smoking rate of the 12th graders was statistically significantly higher than 10th graders and 11 th graders (respectively, p1 $=0.001 ; \mathrm{p} 2=0.024$ ). There was no difference in smoking rate of the 10th and 11 th graders $(p>0.05)$. (Table 4$)$.

Assessing smoking status of the students according to socio-demographic factors has revealed that education status of the mother doesn't affect smoking rate of the students $(p=0.493)$ but education status of the father has led to statistically significant differences in the smoking rate of the students $(p=0.017)$. Dual comparisons on this revealed that students whose fathers graduated from middle school smoke cigarettes more frequently $(26.6 \%)$ than the students whose fathers graduated from primary school (10.8) and University (10.2\%) (respectively, $(p 1=0.023 ; p 2=0.006)$. Moreover, smoking status of the students was also found to be related with male sex, smoking status of the siblings and smoking status of the close friends (all, $p<0.001$ ) (Table 5).

The parameters affecting the smoking status were evaluated with logistic regression. The model was found significant $(p=0.000)$ and the Negelkerke $R$ square value was found to be 0.804 . In the regression model the following parameters were found to be significant: School-private anatolian, school-private occupationaltechnical, smoking status of the siblings, and smoking status among close friends $(p=0.038 ; p=0.0033 ; p=0.000$; $p=0.000$ and $p=0.000$ respectively) (Table 6 ). 
Table1. Socio-demographic Characteristic of the Students

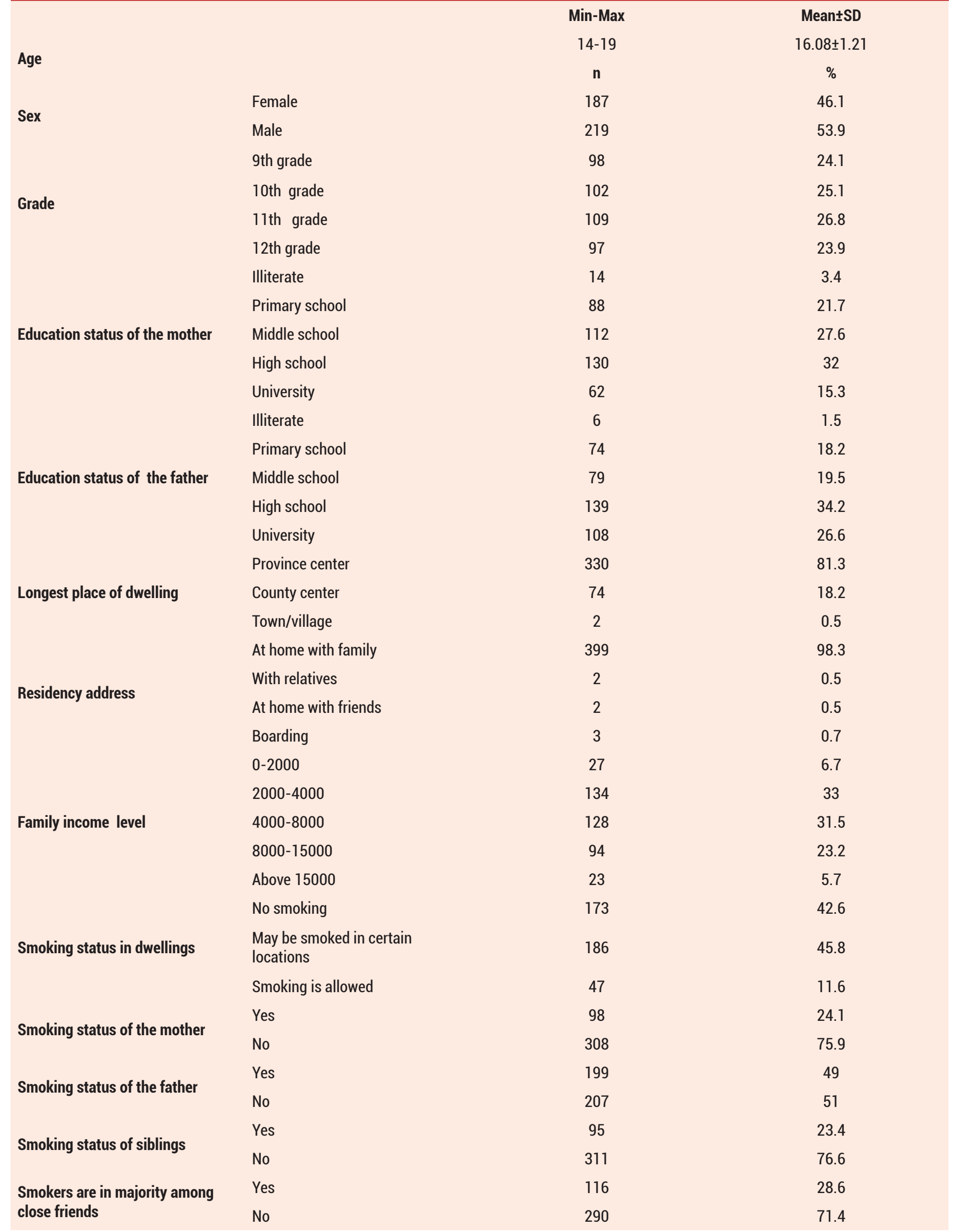


Effects of cigarette smoking is sufficiently told

\section{sing}

Being informed about presence and functioning of outpatient units for cessation of cigarette smoking in health institutions

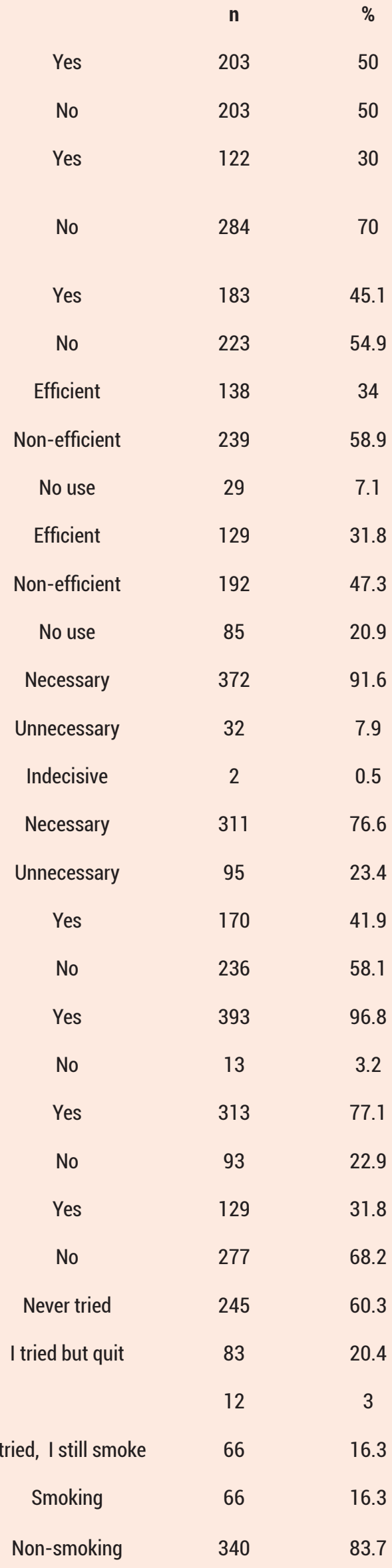

Thinking outpatient units for cessation of cigarette smoking are successful in their

mission

Opinion on warning about harmful effects of smoking on cigarette packs

Opinion on smoking ban in closed spaces

Opinion on cigarette sale ban for people under 18 years old

Is increase in cigarette prices a deterrent for smoking

Thinking smoking cigarette is harmful

Passive exposure to cigarette smoke causes any of the mentioned diseases

Exposure to cigarette smoke in place of dwelling

Tried smoking before

Cigarette smoking status 
Table 3. Distribution of the information about smoking students

Age while starting smoking cigarette $(n=66)$

Duration of smoking cigarette $(n=66)$

Driving factors for starting smoking cigarette $(n=66)$

Number of cigarettes smoked per day (no) $(n=66)$

Desire to quit smoking $(n=66)$

Trial to quit smoking $(n=66)$

(res

Demanding any support when start a trial to quit smoking $(n=66) \quad$ No
11-15 years old

16 years old and over

6 months or less

1 year or less

2 years or less

More than 2 years

Social factors

Curiosity

Enjoyment

Stress/distress

10 or less per week

5 or less per day

5-10 per day

10-20 per day

Yes

No

Yes

No

Yes

Indecisive
$\%$

24.2

75.8

13.6

28.8

25.8

31.8

39.4

21.2

34.8

4.5

13.6

40.9

28.8

16.7

54.5

45.5

77.3

22.7

15.2

66.7

18.2

Table 4. Assessment of smoking status according to the type of attended schools

School

Anatolian high school

Occupational-Technical high school

Private Anatolian

Private Occupational-Technical

9th grade

10th grade

11th grade

12th grade

\section{Smoking status}

Yes

n (\%)

$16(\% 10.4)$

$34(\% 23.3)$

$6(\% 10.9)$

$10(\% 19.6)$

$3(\% 3.1)$

$12(\% 11.8)$

$20(\% 18.3)$

$31(\% 32)$

(2)

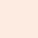

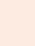




\begin{tabular}{|c|c|c|c|c|}
\hline & & & tatus & $\mathbf{p}$ \\
\hline & & & & \\
\hline & & n (\%) & n (\%) & \\
\hline & Female & $17(\% 9.1)$ & $170(\% 90.9)$ & \\
\hline JeA & Male & $49(\% 22.4)$ & $170(\% 77.6)$ & 0.000 \\
\hline & Illiterate & $2(\% 14.3)$ & $12(\% 85.7)$ & \\
\hline & Primary school & $12(\% 13.6)$ & $76(\% 86.4)$ & \\
\hline $\begin{array}{l}\text { Education status of the } \\
\text { mother }\end{array}$ & Middle school & $24(\% 21.4)$ & $88(\% 78.6)$ & ${ }^{2} 0.493$ \\
\hline & High school & $21(\% 16.2)$ & $109(\% 83.8)$ & \\
\hline & University & $7(\% 11.3)$ & $55(\% 88.7)$ & \\
\hline & Illiterate & $2(\% 33.3)$ & $4(\% 66.7)$ & \\
\hline & Primary school & $8(\% 10.8)$ & $66(\% 89.2)$ & \\
\hline $\begin{array}{l}\text { Education status of the } \\
\text { father }\end{array}$ & Middle school & $21(\% 26.6)$ & $58(\% 73.4)$ & ${ }^{2} 0.017 *$ \\
\hline & High school & $24(\% 17.3)$ & $115(\% 82.7)$ & \\
\hline & University & $11(\% 10.2)$ & $97(\% 89.8)$ & \\
\hline & At home with family & $65(\% 16.3)$ & $334(\% 83.7)$ & \\
\hline nesiuericy auciess & Other & $1(\% 14.3)$ & $6(\% 85.7)$ & 0.001 \\
\hline & $0-2000$ & $2(\% 7.4)$ & $25(\% 92.6)$ & \\
\hline & $2000-4000$ & $26(\% 19.4)$ & $108(\% 80.6)$ & \\
\hline Family income level & $4000-8000$ & $19(\% 14.8)$ & $109(\% 85.2)$ & ${ }^{2} 0.602$ \\
\hline & $8000-15000$ & $15(\% 16)$ & $79(\% 84)$ & \\
\hline & 15000 or above & $4(\% 17.4)$ & $19(\% 82.6)$ & \\
\hline & No smoking & $15(\% 8.7)$ & $158(\% 91.3)$ & \\
\hline $\begin{array}{l}\text { Smoking status in } \\
\text { dwellings }\end{array}$ & $\begin{array}{l}\text { May be smoked in certain } \\
\text { locations }\end{array}$ & $43(\% 23.1)$ & $143(\% 76.9)$ & ${ }^{2} 0.001 *$ \\
\hline & Smoking is allowed & $8(\% 17)$ & $39(\% 83)$ & \\
\hline Smoking status of the & Yes & $20(\% 20.4)$ & $78(\% 79.6)$ & 20201 \\
\hline mother & No & $46(\% 14.9)$ & $262(\% 85.1)$ & 0.201 \\
\hline Smoking status of the & Yes & $39(\% 19.6)$ & $160(\% 80.4)$ & 20074 \\
\hline father & No & $27(\% 13)$ & $180(\% 87)$ & \\
\hline Smoking status of the & Yes & $51(\% 53.7)$ & $44(\% 46.3)$ & 10008 - \\
\hline siblings & No & $15(\% 4.8)$ & $296(\% 95.2)$ & 0.000 \\
\hline Smokers are in majority & Yes & $65(\% 56)$ & $51(\% 44)$ & $10000 *$ \\
\hline among close friends & No & $1(\% 0.3)$ & $289(\% 99.7)$ & \\
\hline
\end{tabular}

Note: If the longest place of dwelling is town/village it's excluded from the analysis because of very low number of cases. Note 2: "With relatives, at home and boarding" answers for the residency address, those were included into the others group because low number of cases. 
Tablo 6. Logistic regression for smoking status and related factors

$\begin{array}{lccc} & \text { OR } & \% 95 \mathrm{Cl} & \mathbf{p} \\ \text { School-Private Anatolian } & 21.931 & 1.195-402.571 & 0.038 * \\ \text { School-Private Occupational-Technical } & 19.857 & 1.275-309.375 & 0.033 * \\ \text { Smoking status of the siblings } & 0.029 & 0.009-0.089 & 0.000 * \\ \text { Smokers are in majority among close friends } & 0.001 & 0.000-0.011 & 0.000 * \\ \text { Constant } & 8.465 & & 0.000 * \\ * \mathrm{p}<0.05 & & & \end{array}$

\section{DISCUSSION}

Since adolescence is an important period regarding first encounters with cigarette smoking and starting to smoke cigarettes, there are substantial studies about smoking habits of students (10,11-12). Treatment of addiction to cigarettes is a difficult process and success rate is not high, thus preventing people from starting to smoke cigarettes is also important. Frequency of smoking cigarettes varies between $15.5 \%-43 \%$ in the studies carried out in our country depending on the populations and regions $(10,11-12)$.

In the study of Gölbaşı et al. carried out in 2011 in Turkey with the title of "cigarette smoking and its frequency among high school students in Turkey" smoking rate was observed as $20.4 \%$ (13). In our study carried out among high school students in Ümraniye county this rate is found as $16.3 \%$. This is consistent with other studies done in Turkey and one out of every 10 students told that they started to smoke cigarettes before 18 years old and this rate cannot be considered unimportant since the addiction rate is higher in individuals starting smoking before 21 years old $(7,8)$.

In the study of Emekdar et al. (14), the rate of smoking cigarettes was $7.1 \%$ among female high school students and $29.9 \%$ among male students. In accordance with the literature smoking rate of male students is statistically significantly higher in male students (\%22.4) than female students $(9.1 \%)$. Higher frequency of smoking cigarettes among males is in conformity with the traditional culture of our country. Males have more freedom to participate in social circles and may easily go to cafes, bars, coffee houses and other entertainment places, thus it's easier for them to encounter addictive substances more than females and consequently to start using these substances (15).

In a study done by Erdamar et al. (16) in Bartın in 2011, smoking status was assessed according to the attended school and smoking rate was found as $14.2 \%$ in Anatolian high school students and $36.2 \%$ in occupational training high schools. In our study, the rate of smoking was statistically significantly lower in Anatolian school students (10.4) compared to the students in occupational training high schools (23.3\%). Higher rates in occupational training schools may be related with more strict superintendence in Anatolian high schools. Moreover, it can be suggested that, concentration of Anatolian high school students to study their lessons to achieve success in academic institutions and exams may attenuate their tendency to start smoking. The students in Occupational Training high schools may have more tendency to begin harmful habits because of their perceptions about themselves as being less successful, because they spend less time studying lessons for school and exam success, and because their objectives and targets for future is uncertain.

According to GYTS data, $15 \%$ of tobacco smokers between 15-34 years old have started smoking before 15 years old. This rate is $57.5 \%$ if the cut off age is 18 years. Mean age for starting smoking is 17 years (17). In our study $75.8 \%$ of the students have started to smoke cigarettes at 16 years old or over. These results have revealed that required preventive guidance should be given to high school students at early ages before they start smoking.

In our study, in line with other studies performed in Turkey $(11,18,19)$ smoking frequency has increased by increasing the age and grade of the students. 9th grade smokers (3.1\%) were statistically significantly lower than 10th grade (11.8\%), 11 th grade $(18.3 \%)$ and 12 th grade $(32 \%)$ smokers. Moreover, as the grade and age of the students increase their attitudes toward cigarette smoking become more positive.

Normally, smoking frequency of the students decreases by increase in the education level of their parents (20). However, in our study, there was no difference in smoking frequency of the students and education level of their parents. There is statistically significant correlation between smoking frequency of the patients and education status of their fathers'. If the fathers graduated from middle school smoking frequency of the students $(26.6 \%)$ was significantly higher compared to the smoking frequency of the students whose fathers 
graduated from primary school $(10.8 \%)$ or university (10.2\%): smoking frequency of the students decreased by increasing the education level of the fathers. And this result is consistent with the predicted result. The reason for the low smoking rate among students whose fathers are primary school graduates may be due to fathers' lower purchasing power resulting from their employment in lower income jobs. More study results are required in order to understand how actually students' smoking behavior is affected by the education status of the parents or to determine if the results obtained from this study is unique only for the population of this study or not.

In our study, there was no significant difference in smoking frequency of students due to the education status of their parents, but smoking frequency of students whose siblings also smoke (53.7\%) was significantly higher compared to those whose siblings don't smoke (4.8). These results may suggest that adolescents don't take their parents as role models. When the studies in the literature evaluated; in the studies of Çelik et al. (18) and Berk et al. (19), in line with our study, there was no correlation between smoking frequency of students and smoking status of their parents but there was significant correlation between smoking frequency of students and smoking status of their siblings.

In some studies carried out countrywide in Turkey, the most important factor affecting smoking behavior of the students was found to be close friendship circles (18,21-23). In our study frequency of cigarette smoking was statistically significantly higher in students having majority of close friends who are also smoking (56\%) compared to students whose close friends generally don't smoke (0.3\%).

In the study of ilhan et al. (24) and Mayda et al. (25) "peer effect" was found as the most common cause. When we assess the reason for starting cigarette smoking among students, $39.4 \%$ stated that they started smoking because of social factors (friends, social environment etc.) $34.8 \%$ said they had pleasure, $21.2 \%$ said as a whim and $4.5 \%$ said because of stress/distress. In our study, we found a correlation between starting smoking and peer effect as a common result of two different questions in our questionnaire and this finding may suggest that friends have an important role in the life of adolescents and this factor is very important for indulging in adolescents' bad habits. It's observed in our study that there is widespread misinformation and thoughts about cigarettes among students who smoke cigarettes and they are satisfied with their habit and don't think to quit smoking. Seeing tougher attitudes of non-smokers against smoking have led us to the conclusion that, as a preventive measure, to prevent first trial is an important act. Emotional instability of the adolescents during their psychological development, attitudes such as standing up against authority, trying to resemble someone who is admired, being affected by family members, emulation of friends, peer pressure reinforced by the effect of social environment may facilitate starting smoking during high school period (26). At this period, taking someone as a role model is very important for learning. During this period, adolescents are affected from positive or negative attitudes and behaviors of personality figures such as young teachers or community leaders (27).

In our study frequency of smoking was markedly higher among students whose siblings also smoke and this result indicates how important family members are for first encounters with cigarette smoking and acquiring smoking habits. Moreover, higher frequency of smoking among students whose close friends also smoke shows us how effective close friends can be on adolescents. These effects may also be used positively to educate students on harmful effects of cigarette smoking and to support them on their effort to quit smoking. There are studies that achieved successful results by peer education. Education programs promoting peer education and solidarity among youth should be planned and supporting peers should be encouraged among adolescents. After studies similar to ours are also evaluated, we suggest that in order to be more effective, in addition to smoking ban school-based programs; population-based programs and mass-media should also be used to prevent adolescents from starting to smoke. Pediatricians and family doctors should also question the adolescents about smoking habits and behaviors during their visit for routine adolescent follow up exams. This kind of a query may be an important step in detection of young students who are smoking at the early stage and taking necessary measures to prevent further smoking.

\section{LIMITATIONS}

Although required permissions were obtained from official institutions, reluctance of some school managements, and unwillingness of 12th grade to participate in the study because of the anxiety of the upcoming university entrance test ended up with some limitations for the sample distribution. This limitation and the fact that our study has taken place only in one county make it difficult to generalize the results to the whole population.

\section{CONCLUSION}

In the study we have done to assess frequency of cigarette smoking among high school students and their attitudes and behaviors regarding cigarette smoking, we have found the frequency of smoking as $16.3 \%$. Male sex, being a student of occupational training high school, attending to higher grades, lower education status of the father, having smoking siblings and having smoking close friends were all factors increasing the risk of starting to smoke cigarette. Despite all preventive measures carried out in schools, cigarette smoking is still prevalent among high school students and first encounter with smoking usually happens at that period; thus there is a need for designing and performing wider research similar to ours. 
Financial disclosures: All authors report no financial interests or potential conflicts of interest.

Conflict of Interest: The authors declare that they have no competing interest.

Ethical approval: This article has been approved by the Istanbul Health Sciences University Clinical Research Ethics Committee. protocol number H.GP.0.01 / 54

\section{REFERENCES}

1. Don't Let Tobacco Take Your Breath Away. [Internet]. World Health Organization (WHO), https://apps.who.int/ iris/bitstream/handle/10665/312260/WHO-NMH-PND2019.3-eng.pdf access date 28.08.2020

2. 10 Facts On The Global Tobacco Epidemic. [Internet]. World Health Organization(WHO), https://www.who.int/features/ factfiles/tobacco_epidemic/tobacco_epidemic_facts/en/ access date 28.08.2020

3. U.S. Department of Health and Human Services. The Health Consequences of Smoking - 50 Years of Progress: A Report of the Surgeon General. Atlanta: U.S. Department of Health and Human Services, Centers for Disease Control and Prevention, National Center for Chronic Disease Prevention and Health Promotion, Office on Smoking and Health, 2014 Erişim: https://www.surgeongeneral.gov/library/ reports/50-years-of-progress/full-report.pdf access date 28.08.2020

4. Wang C, Horby PW, Hayden FG, et al. A novel coronavirus outbreak of global health concern. Lancet (London, England).2020;395:4703.

5. Smoking and COVID-19. [Internet]. World Health Organization (WHO), https://www.who.int/publications/i/ item/WHO-2019-nCoV-Sci_Brief-Smoking-2020.2 access date 28.08.2020

6. Özata Ö, Kazkayası M. The effects of cigarette on medical and surgical treatment of ear nose and throat diseases. KBB-Forum. 2010;9:40-6.

7. Kulaksızoglu A. Adolescent psychology. Istanbul: Remzi Bookstore, 2004:206.

8. World Health Organization. WHO Report On The Global Tobacco Epidemic, Brazil 2008.

9. Stop Tobacco Industry Exploitation Of Children and Young People. [Internet]. World Health Organization (WHO), https://www.who.int/news-room/detail/29-05-2020-stoptobacco-industry-exploitation-of-children-and-youngpeople access date 28.08.2020

10. Türkiye İstatistik Kurumu Küresel yetişkin tütün kullanım istatistikleri, 2016. http://tuik.gov.tr/PreTablo.do?alt_ $\mathrm{id}=1042$ access date 29.08 .2020

11. Akkus D, Karaca A, Sener DK, et al. The Prevalence of Tobacco and Alcohol Use in High School Students and the Affecting Factors, Anatolian Clinic 2017;1:36-45.
12. Tümerdem $Y$, Ayhan B, Emekli $U$ et al. Smoking habits in students in Istanbul. Respiratory. 1986;12-6.

13. Gölbaşı Z, Kaya D, Çetindağ A, et al. Smoking Prevalence and Associated Attitudes among High School Students in Turkey. Asian Pac J Cancer Prev. 2011;11:1313-6.

14. Emekdar G, Çıtıl R, Önder $Y$, et al.Smoking Prevalence and Related Factors Among Secondary and High School Students in Tokat Province. J Contemp Med. 2017; 7:1-8.

15. Aksoy K. High school students' attitudes towards addictive substances and investigation of the variables affecting these attitudes (Malatya city sample). İnönü University Institute of Social Sciences; 2006

16. Erdamar G, Kurupınar A. The Habit of Drug Addiction and Prevalence Among the Secondary School Students: Sample of Bartın City. Bartın University Institute of Social Sciences; 2014.

17. Yilmaz F. Thoughts on Tobacco: In West and in Our Country. Gürsoy Naskali E, editor. The Book of Tobacco. Istanbul Bookstore, 2003:195.

18. Celik P, Esen A, Yorgancıoglu A, et al. Attitudes of High School Students towards Smoking in Manisa, The Journal of Thorax, 2000;1:61-6.

19. Berk S, Doğan, ÖT, Nur N.Smoking Habits and Attitudes of High School Students Towards Smoking in AgrlDogubayazit, Cumhuriyet University, Journal of Medical Faculty, 2007,29:149-55.

20. Sönmez Cl, Başer DA, Aydoğan S. Evaluation of Knowledge, Attitudes, Behaviors and Frequency of Smoking among Medical Students of Düzce University. Konuralp Medical Journal 2017. 9;83-89.

21. Çayan A, Çelik P, Özyurt B, et al. Smoking prevalence of elementary school students in Manisa, Tuberculosis and Thorax, 2018;66:224-33.

22. Karatay G, Kubilay G. The determination of substance use and influenced factors at two highschool; which have different socio-economic status. Hemşirelikte Araştırma ve Geliştirme Dergisi 2004;2;57-70.

23. Ergüder $\mathrm{T}$, Soydal $\mathrm{T}$, Uğurlu $\mathrm{M}$ et al. Global youth tobacco Turkey research. Ministry of Health Substance Abuse Branch Office. 2003.

24. İlhan $F, A$ ksakal $N$, İlhan $M N$, et al. Smoking prevalence among Gazi University Faculty of Medicine. TSK Koruyucu Hekimlik Bülteni 2005;4:188-98.

25. Mayda AS, Tufan N, Baştaş S. Attitudes towards smoking and frequency of smoking among students of Düzce Medical School. Kor Hek 2007;6:364-70.

26. Pekşen Y. Health Effects of Smoking and Cessation Methods. Instanbul: Logos Publishing. 1995: 29-53.

27. Herken H, Özkan İ, Çilli AS, et al. social learning on smoking effect. Journal of Dependence 2000; 1:38-42. 